\title{
Peningkatan Efektivitas Mesin Susu Kental Manis dengan Metode Overall Equipment Effectiveness dan Diagram Ishikawa
}

\author{
Mohammad Cipto Sugiono $^{1 *}$, Risal Ngizudin ${ }^{2}$ \\ ${ }^{1,2}$ Teknologi Industri ITS NU Pekalongan \\ Jl. Karangdowo No.9 Kedungwuni Kab.Pekalongan 51173 \\ 1*moh_cipto425@yahoo.co.id
}

\section{Effectiveness Improvement of Sweetened Condensed Milk Sachet Filling Machine with Overall Equipment Effectiveness Method and Ishikawa's Diagram}

Dikirimkan : 04, 2021. Diterima : 06, 2021. Dipublikasikan : 09, 2021

\begin{abstract}
PT.X is an industrial company that runs in milk processing which manufactured variety products of its derivative. The problem that PT. $X$ has are the high rate of breakdown and planned downtime that happened in sweetened condensed milk sachet filling machine, resulting a low value of availability rate in 2020. These problems can be solved by using Overall Equipment Effectiveess (OEE) method as an identification of those problems and Ishikawa's Diagram as a proposed further improvement. The average measurement result of OEE in sweetened condensed milk sachet filling machine in the year of 2020 is $71.90 \%$. This result shows us that the percentage of OEE still hasn't reached the company's target which is 75\%. That low achievement of OEE is caused by one dominated factor which is the value of availability rate. According to Ishikawa's Diagram, the main cause of the low value of availability rate are preventive maintenance, autonomous maintenance and predictive maintenance which become the cause of the recent breakdown. In conclusion, if the maintenance is done properly and thoroughly, the breakdown will certainly happen rarely, so that the value of the availability rate will also rise.
\end{abstract}

Keywords : Overall Equipment Effectiveness; Diagram Ishikawa; Maintenance

\begin{abstract}
Abstrak-PT. X adalah perusahaan industri yang bergerak di bidang pengolahan susu yang memproduksi berbagai produk turunannya. Masalah yang terjadi di PT. X adalah tingginya tingkat kerusakan dan downtime terencana yang terjadi pada mesin pengisi sachet susu kental manis, sehingga mengakibatkan rendahnya nilai availability rate pada tahun 2020. Permasalahan tersebut dapat diatasi dengan menggunakan metode Overall Equipment Effectiveess (OEE) sebagai identifikasi permasalahan tersebut. Hasil pengukuran rata-rata OEE pada mesin pengisi susu kental manis sachet tahun 2020 adalah 71,90\%. Hasil ini menunjukkan bahwa persentase OEE masih belum mencapai target perusahaan yaitu 75\%. Rendahnya pencapaian OEE tersebut disebabkan oleh salah satu faktor yang mendominasi yaitu nilai availability rate. Menurut diagram Ishikawa, penyebab utama rendahnya nilai tingkat ketersediaan adalah maintenance preventive, maintenance otonom, dan maintenance prediktif yang menjadi penyebab kerusakan mesin.
\end{abstract}

Kata kunci Overall Equipment Effectiveness; Ishikawa's Diagram; Maintenance

\section{PENDAHULUAN}

Pada saat ini kebutuhan akan mesin canggih atau peralatan produksi semakin meningkat. Walaupun demikian terdapat beberapa faktor yang dapat mempengaruhi efektivitas dan produktivitas peralatan produksi tersebut antara lain dari sisi perawatan mesin, operator dan hal lainnya. Salah satu upaya yang dilakukan oleh perusahaan adalah dengan meningkatkan efektivitas mesin secara optimal. .Namun sering kali perbaikan yang 
dilakukan tidak tepat sasaran sehingga cenderung mengakibatkan borosnya biaya dan waktu. Untuk itu dibutuhkan suatu metode yang dapat menemukan akar masalah yang terjadi sehingga perbaikan yang dilakukan akan efektif dan efisien serta berjalan secara optimal.

Salah satu metode yang dapat digunakan untuk mengukur kinerja dan efektivitas mesin adalah Overall Equipment Effectiveness (OEE). Metode Pengukuran $O E E$ memiliki tiga faktor utama yang saling memiliki keterkaitan yaitu Availability (ketersediaan), Performance (kemampuan), dan Quality (kualitas).

Keunggulan dari OEE adalah simpel, namun tetap komprehensif, dapat mengukur tingkat efisiensi internal dan dapat digunakan sebagai tolak ukur perbaikan secara terus menerus [1]. OEE merupakan metode yang efektif untuk mengukur efisiensi mesin tunggal atau sebuah sistem mesin yang terintegrasi [2]. Semua perusahaan pasti mengharapkan mesinnya memiliki performa yang maksimal yang terbebas dari downtime, dan tidak memiliki defect pada produk yang dihasilkan. Tapi untuk mencapai kondisi tersebut dalam kenyataannya sangat sulit dicapai namun masih ada peluang untuk mengoptimalkannya. Menghitung OEE merupakan salah satu metode untuk mengurangi kerugian yang ditimbulkan oleh peralatan produksi maupun pada proses produksinya. Dengan pengukuran OEE ini maka kita akan mengetahui faktor apa saja yang menyebabkan kinerja dan efektivitas suatu mesin atau peralatan produksi rendah atau buruk. Dari metode pengukuran OEE, departemen maintenance pada perusahaan akan berfokus pada faktor penyebab buruknya kinerja mesin untuk meningkatkan kinerja dan efektivitas mesin sehingga kegiatan perbaikan yang dilakukan lebih efektif karena langsung menyentuh akar permasalahan.

PT. X merupakan sebuah industri pengolahan susu yang pasarnya hampir sampai ke seluruh Indonesia. PT. $\mathrm{X}$ ini membuat 3 jenis macam produk, yaitu susu kental manis, susu cair, dan susu bubuk. Masalah yang terjadi pada PT. X adalah tingginya tingkat kerusakan dan downtime terencana yang terjadi pada mesin pengisi sachet susu kental manis, sehingga mengakibatkan rendahnya nilai availability rate, sehingga digunakan metode OEE dalam mengukur kinerja mesin yang ada pada lini produksi sehingga diketahui yang memenuhi. Perlu diketahui proses pembuatan susu kental manis dibagi menjadi 4 sub lini, yaitu sub lini pemrosesan, sub lini can, sub lini sachet, dan sub lini bulk, pada penelitian ini melihat bahwa banyak terjadi breakdown pada saat waktu produktif contohnya seperti kode laser yang tidak terbaca, rantai kendur, pisau cutting yang tumpul.
Dalam penelitian ini hanya dilakukan penelitian pada mesin filling sachet.

\section{METODOLOGI PENELITIAN}

\section{A. Pengumpulan Data}

Dalam proses penelitian ini penulis hanya menjalankan kegiatan berdasarkan rencana kegiatan yang sudah penulis buat. Di sini penulis mengumpulkan data, yaitu:

1. Waktu jam kerja mesin filling sachet susu kental manis.

2. Waktu perbaikan yang direncanakan oleh pihak teknisi.

3. Waktu kerusakan mesin filling sachet.

4. Waktu setup mesin filling sachet.

5. Teorytical cycle time mesin filling sachet.

6. Jumlah output yang diproduksi.

7. Jumlah output yang cacat.

8. Jumlah permintaan konsumen.

\section{B. Metode Pengumpulan Data}

Metode yang digunakan untuk mengumpulkan data pada penelitian ini adalah:

1. Wawancara, yaitu dengan menggali informasi dari pihak-pihak yang berhubungan dengan perusahaan.

2. Data-data perusahaan baik yang berupa data produksi, dokumentasi dan data yang berhubungan dengan perusahaan.

3. Observasi langsung, yaitu dengan mengamati proses produksi yang sedang berlangsung.

\section{Sumber dan Jenis Data}

Sumber data yang digunakan dalam penelitian berasal dari internal perusahaan. Sedangkan jenis data yang digunakan adalah data primer dan sekunder yang diperoleh dari perusahaan tempat dilaksanakan penelitian. Adapun rincian dari data tersebut adalah sebagai berikut

Data Primer berupa :

1. Aliran proses produksi

2. Waktu kerja mesin filling sachet

3. Waktu perbaikan yang direncakan oleh pihak teknisi

4. Waktu kerusakan mesin filling sachet

5. Waktu setup mesin filling sachet

6. Data jumlah output produk

7. Data jumlah output produk cacat

8. Data teoritycal cycle time mesin filling sachet

Sedangkan data Sekunder :

1. Komposisi bahan

2. Data permintaan suatu hasil produk / jasa perusahaan 


\section{Metode Pengolahan Data}

1) Menghitung Availability rate

Menghitung availability rate mesin filling sachet dari dengan menggunakan data jam kerja mesin filling sachet, waktu perbaikan yang direncanakan oleh pihak teknisi, waktu kerusakan mesin filling sachet, dan waktu setup mesin filling sachet. Dalam perhitungannya penulis menggunakan Microsoft excel. Untuk menghitung nilai availability rate digunakan rumus sebagai berikut:

$$
\text { Availability }=\frac{\text { loading time-downtime }}{\text { loading time }} \times 100 \%
$$

2) Menghitung Performance Rate

Menghitung Performance Rate mesin filling sachet dengan menggunakan data teoritycal cycle time mesin filling sachet, jumlah output produksi, dan waktu operasi mesin filling sachet. Dalam perhitungannya penulis menggunakan Microsoft excel, untuk menghitung nilai perfomance rate digunakan rumus sebagai berikut:

$$
\begin{aligned}
& \text { Performance Rate }= \\
& \frac{\text { Theoritical cyle time-Output }}{\text { Operating Time }} \times 100 \%
\end{aligned}
$$

\section{3) Menghitung Quality Rate}

Menghitung quality rate mesin filling sachet dengan menggunakan data jumlah output yang diproduksi dan jumlah output yang cacat. Dalam perhitungannya penulis menggunakan Microsoft excel, untuk menghitung nilai Quality rate digunakan rumus sebagai berikut:

$$
\text { Quality Rate }=\frac{\text { output-Total Scrap }}{\text { Output }} \times 100 \%
$$

\section{4) Menghitung Nilai OEE}

Menghitung nilai $O E E$ mesin filling sachet dengan menggunakan data availability rate, performance rate, dan quality rate. Dalam perhitungannya penulis menggunakan Microsoft excel. Untuk menghitung nilai $O E E$ digunakan rumus sebagai berikut:

OEE $=$ Availability rate $x$ Performance Rate $x$ Quality Rate

\section{5) Analisis}

Setelah menghitung nilai OEE dan menentukan faktor apa yang paling berpengaruh terhadap nilai OEE, peneliti melakukan analisis penyebab rendahnya faktor yang mempengaruhi OEE.

\section{6) Membuat diagram Ishikawa}

Membuat diagram ishikawa berdasarkan masalah yang terjadi pada lini produksi serta
Sistem Industri

menganalisis penyebab - penyebab apa saja yang menyebabkan faktor nilai OEE menjadi rendah.

\section{7) Membuat Usulan Perbaikan}

Membuat usulan perbaikan berdasarkan masalah yang sudah dipetakan pada diagram ishikawa.

\section{HASIL PENELITIAN}

A. Produk

Susu kental manis merupakan susu yang terbuat dari susu murni yang dicampur dengan gula, dihomogenisasi dan dipasteurisasi, kemudian ditambahkan dengan berbagai vitamin.

Adapun bahan yang digunakan untuk membuat susu kental manis adalah sebagai berikut:

a. Susu sapi murni segar

b. Susu bubuk skim

c. Gula murni

d. Lemak tumbuhan

e. Laktosa

f. Kalsium, Fosfor, Zink, Vit A, Vit B1 serta mengandung vitamin B2, B3, B6, B12 \& D3

g. Bubuk coklat .

Dengan menggunakan sistem produksi yang canggih, penambahan gula dan pengurangan kandungan air, susu kental manis menjadi susu yang memiliki daya tahan yang lama yaitu selama 12 bulan. Pada susu coklat digunakan penambahan coklat murni sehingga memiliki kandungan gizi yang lebih tinggi apabila dibandingkan dengan susu yang ditambahkan dengan perasa coklat. Kandungan Vitamin A, B1 dan D3 sangat bagus untuk mendukung pertumbuhan tubuh. Untuk varian produk ada yang plain dan coklat serta dengan kemasan kaleng dengan berat 375 gram dan sachet 40 gram.

Susu kental manis merupakan hasil olahan susu segar yang mempunyai shelf life selama (12 bulan) dengan penanganan yang cukup mudah. Selain itu dengan penambahan gula dan reduksi kandungan air pada produk ini, susu kental manis menjadi awet meskipun tanpa bahan pengawet tambahan. Berikut merupakan proses pengolahan susu kental manis : 


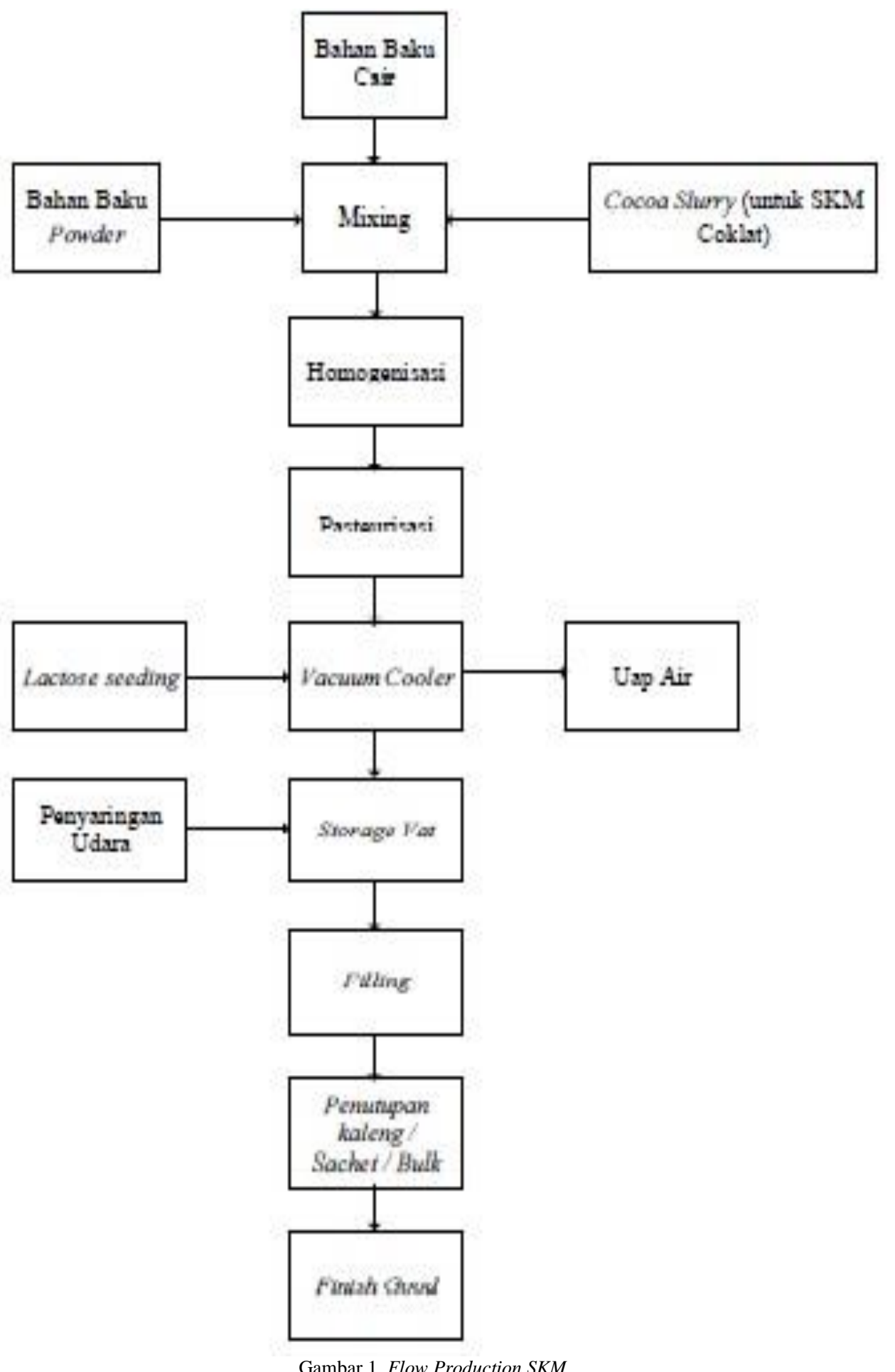

\section{B. Perhitungan Availability Rate}

Availability rate dapat menunjukan ketersediaan waktu yang dibutuhkan suatu mesin atau alat untuk melakukan suatu operasi. Data-data yang digunakan dalam pengukuran Availability rate adalah waktu kerja mesin, planned downtime, downtime (failure dan setup and adjustment time). Berdasarkan hasil perhitungan availabilty rate dari data yang diperoleh dari PT. X sebagai berikut:

$$
\text { Waktu kerja mesin } \quad=458 \text { jam }
$$

$$
\begin{array}{ll}
\text { Planned downtime } & =98.7 \text { jam } \\
\begin{array}{ll}
\text { Loading time } \\
\text { mesin }- \text { planned downtime })
\end{array} & =(\text { waktu kerja } \\
& =458-98.7 \\
& =359.3 \mathrm{jam} \\
\text { Failure } & =97.2 \\
\text { Jam Setup \& adjustment } & =6.6 \mathrm{jam} \\
\text { Downtime } & =103.8 \mathrm{jam}
\end{array}
$$




$$
\begin{aligned}
\text { Availability } & =\frac{359,3-103,8}{359,3} \times 100 \% \\
& =71.11 \%
\end{aligned}
$$

Maka dapat diketahui bahwa nilai availability rate mesin filling sachet pada bulan Januari adalah sebesar $71.11 \%$.

\section{Perhitungan Performance Rate}

Performance Rate menunjukkan kemampuan mesin atau peralatan dalam menghasilkan barang. Untuk menghitung Performance Rate, diperlukan beberapa data yaitu kecepatan produksi teoritis, jumlah output, dan waktu operasi. Berdasarkan hasil perhitungan Performance Rate dari data yang diperoleh dari PT. X sebagai berikut:

Theoritical cycle time $=912 \mathrm{crt} / \mathrm{jam}=$ $0.001096491 \mathrm{jam} / \mathrm{crt}$

$$
\begin{aligned}
& \begin{array}{l}
\text { Output }=253,920 \mathrm{crt} \\
\text { Tabel }=255.5 \mathrm{jam}
\end{array} \\
& \begin{aligned}
\text { Performance Rate } & =\frac{0.001096491-253,920}{255,5} \times 100 \% \\
& =108.97 \% \sim 100 \%
\end{aligned}
\end{aligned}
$$

Maka dapat diketahui bahwa nilai Performance Rate mesin filling sachet pada bulan Januari adalah sebesar $100 \%$.

\section{Perhitungan Quality Rate}

Quality rate menunjukkan kemampuan mesin atau peralatan dalam menghasilkan produk yang sesuai dengan standar produk yang diinginkan. Untuk menghitung quality rate data yang digunakan adalah output dan jumlah produk cacat (scrap).

Quality rate dapat dihitung dengan rumus berikut :

$$
\begin{aligned}
& \text { Output } \quad=253920 \mathrm{crt} \\
& \text { Total scrap / defect }=146.875 \mathrm{crt}
\end{aligned}
$$

Maka dapat diketahui bahwa nilai quality rate mesin filling sachet pada bulan Januari adalah sebesar $99.94 \%$.

\section{E. Perhitungan Overall Equipment Effectiveness}

Setelah mendapatkan nilai faktor ketersediaan, faktor performansi, dan faktor kualitas. Maka dari hasil perhitungan Overall Equipment Effectiveness dari data yang diperoleh dari PT. X sebagai berikut:

$$
\begin{aligned}
& \text { Availability Rate }=71.11 \% \\
& \text { Performance Rate }=100 \% \\
& \text { Quality Rate = } 99.94 \% \\
& \text { OEE }=71.11 \% \text { X } 100 \% \text { X } 99.94 \% \\
& =71.07 \%
\end{aligned}
$$

Maka dapat diketahui bahwa nilai $O E E$ mesin filling sachet pada bulan Januari adalah sebesar $71.07 \%$.
Sistem Industri

Dari hasil tersebut dapat diperoleh nilai $O E E$ dibandingkan dengan standar dunia sebagai berikut

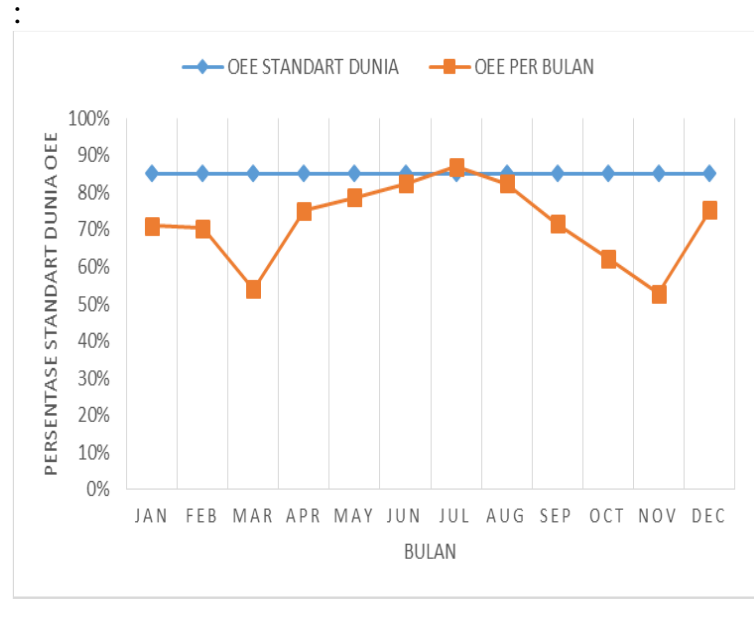

Gambar 2. Chart nilai OEE januari-desember

Sedangkan rata - rata nilai faktor $O E E$ dan rata - rata nilai $O E E$ selama 12 bulan =dapat dilihat pada tabel berikut :

TABEL II

NILAI RATA-RATA FAKTOR $O E E$

\begin{tabular}{cc}
\hline Faktor & Nilai \\
\hline Rata-rata Availability & $77,71 \%$ \\
Rata-rata Performance & $93,00 \%$ \\
Rata-rata Quality & $99,99 \%$ \\
Rata-rata OEE & $71,90 \%$ \\
\hline
\end{tabular}

\section{IV.PEMBAHASAN}

\section{A. Standar Dunia OEE}

Nilai Overall Equipment Effectiveness (OEE) sangat baik digunakan sebagai indikator untuk mengetahui dan mengukur produktivitas sebuah objek. Objek yang dimaksud tidak hanya mesin, namun juga bisa saja manusia serta material yang berhubungan dengan proses produksi. Hasil yang didapat pada pengolahan data telah mendeskripsikan bagaimana nilai keefektifan total dari mesin filling sachet. Menurut [3] nilai ideal dari OEE adalah :

TABEL I

BATAS STANDAR DUNIA OEE

\begin{tabular}{cc}
\hline & Nilai \\
Faktor & Batas \\
& Standar \\
& Dunia \\
\hline Availability Rate & $>90 \%$ \\
Performance Rate & $>95 \%$ \\
Quality Rate & $>99 \%$ \\
OEE & $>85 \%$ \\
\hline
\end{tabular}




\section{B. Analisis Availability Rate}

Availability rate menunjukkan waktu yang dibutuhkan mesin untuk suatu proses dibandingkan dengan waktu yang telah ditetapkan sebelumnya. Availability rate menunjukkan perkiraan atau peluang waktu sistem untuk melaksanakan operasi dalam suatu waktu dalam kondisi tertentu. Pada perhitungan availability rate sendiri dipengaruhi oleh beberapa faktor, yaitu tabel, loading time, planned downtime, failure \& repair time, dan setup $\&$ adjustment time.

Dari perhitungan yang telah dilakukan, diperoleh nilai availability rate untuk mesin filling sachet SKM pada PT. X selama 12 bulan dari bulan Januari - Desember. Dengan nilai rata - rata availability rate sebesar $77.71 \%$, sedangkan nilai availability rate paling rendah terjadi pada bulan Oktober sebesar $62.27 \%$. Berdasarkan data excel dari bagian produksi hal ini dikarenakan lamanya waktu breakdown dan planned downtime sehingga menyebabkan banyak waktu produktif mesin yang terbuang, seperti breakdown yang sering terjadi seperti pada proses cutting macet, foil pelipat tidak presisi, kode laser tidak tercetak, kopling slip. Sedangkan nilai availability rate paling tinggi terjadi pada bulan september sebesar $98.51 \%$, hal ini dikarenakan waktu breakdown dan planned downtime bisa diminimalisir sehingga tidak terlalu menggangu ketersediaan mesin untuk beroperasi. Tapi ternyata nilai rata - rata availability rate dari mesin filling sachet SKM masih berada di bawah nilai standar dunia OEE, yaitu sebesar $90 \%$. Karena masih ada jarak yang cukup jauh untuk mencapai standar dunia karena nilai availability rate rata rata hanya mencapai $77.71 \%$, yang artinya masih banyak waktu produktif mesin yang terbuang.

\section{Analisis Performance Rate}

Performance Rate menunjukkan kemampuan dari peralatan dalam menghasilkan output. Performance Rate perbandingan kecepatan operasi aktual dari mesin dengan kecepatan ideal dari mesin tersebut berdasarkan kapasitas produksi. Performance Rate dipengaruhi oleh beberapa faktor, yaitu jumlah output, theorytical cycle time, dan operating time.

Dari perhitungan yang telah dilakukan, diperoleh nilai Performance Rate untuk mesin performance rateSKM pada PT. X selama 12 bulan dari bulan Januari - Desember. Dengan nilai rata rata Performance Rate sebesar $93.00 \%$, sedangkan nilai Performance Rate paling rendah terjadi pada bulan November sebesar $65.81 \%$.. Nilai rata - rata Performance Rate untuk 12 bulan adalah sebesar 93\% yang berarti mesin filling sachet SKM hampir memenuhi standar dunia untuk nilai performance rate.

\section{Analisis Quality Rate}

Quality Rate menunjukkan kemampuan peralatan / mesin dalam menghasilkan produk yang sesuai dengan standart yang diinginkan perusahaan. Quality Rate dipengaruhi oleh beberapa faktor, yaitu jumlah dan total scrap yang dihasilkan oleh mesin.

Dari perhitungan yang telah dilakukan, diperoleh nilai Quality Rate untuk mesin performance rate SKM pada PT. X selama 12 bulan dari bulan Januari - Desember. Dengan nilai rata rata Quality Rate sebesar $99.99 \%$. Dengan nilai Quality Rate sebesar ini, artinya output yang dihasilkan mesin filler sudah melampaui standart dunia yaitu sebesar 99\%. Dengan begitu kualitas output dari mesin performance rateini harus dipertahankan.

\section{E. Analisis $O E E$}

Perhitungan Overall Equipment Effectiveness (OEE) dilakukan untuk mengukur tingkat produktivitas mesin performance ratepada bulan Januari - Desember 2020. Pengukuran OEE merupakan gabungan dari kecepatan produksi, tingkat kualitas operasi mesin, waktu yang dibutuhkan untuk produksi

Nilai OEE dipengaruhi oleh Quality Rate dan berdasarkan perhitungan dapat diketahui bahwa tingkat kualitas yang dihasilkan mesin performance rate sangat baik yaitu $99.99 \%$. Sehingga dapat dikatakan moto PT. X "Quality First" dapat dikatakan telah tercapai. Sedangkan nilai Performance rate dari mesin performance rate juga dapat dinyatakan baik yaitu sebesar 93\%. Akan tetapi ada faktor lain yang masih memiliki nilai yang menyebabkan tingkat efektivitas performance rate kurang baik, yaitu availability rate yang sebesar $77.71 \%$ karena perbedaan jarak yang cukup banyak antara availability rate $\mathrm{PT}$. X dengan availability rate pada standar dunia.

TABEL III

PERBANDINGAN NILAI MESIN FILLING DENGAN STANDAR DUNIA

\begin{tabular}{ccc}
\multicolumn{3}{c}{ STANDAR DUNIA } \\
\hline Faktor & $\begin{array}{c}\text { Nilai Rata - rata } \\
\text { Mesin Filling }\end{array}$ & $\begin{array}{c}\text { Nilai Batas } \\
\text { Standar } \\
\text { Dunia }\end{array}$ \\
\hline $\begin{array}{c}\text { Availability } \\
\text { Rate } \\
\text { Performance } \\
\text { Rate } \\
\text { Quality Rate }\end{array}$ & $77.71 \%$ & $90 \%$ \\
OEE & $93.00 \%$ & $95 \%$ \\
\hline
\end{tabular}

\section{F. Analisis Dengan Diagram Ishikawa}

Diagram Ishikawa adalah metode yang digunakan untuk mencari akar permasalahan sehingga dengan ditemukannya akar masalah tersebut maka penanganan masalah dapat tepat sasaran dan tidak menimbulkan pemborosan. 
Jurnal Media

Teknik dan

Sistem Industri

Berdasarkan hasil observasi yang dilakukan di PT $\mathrm{X}$, diperoleh keterangan bahwa OEE mesin performance rate SKM pada PT. X kurang adalah nilai availability rate, maka untuk mengidentifikasi penyebabnya digunakan diagram Ishikawa, sebagai berikut : memuaskan yang faktor dominan penyebabnya

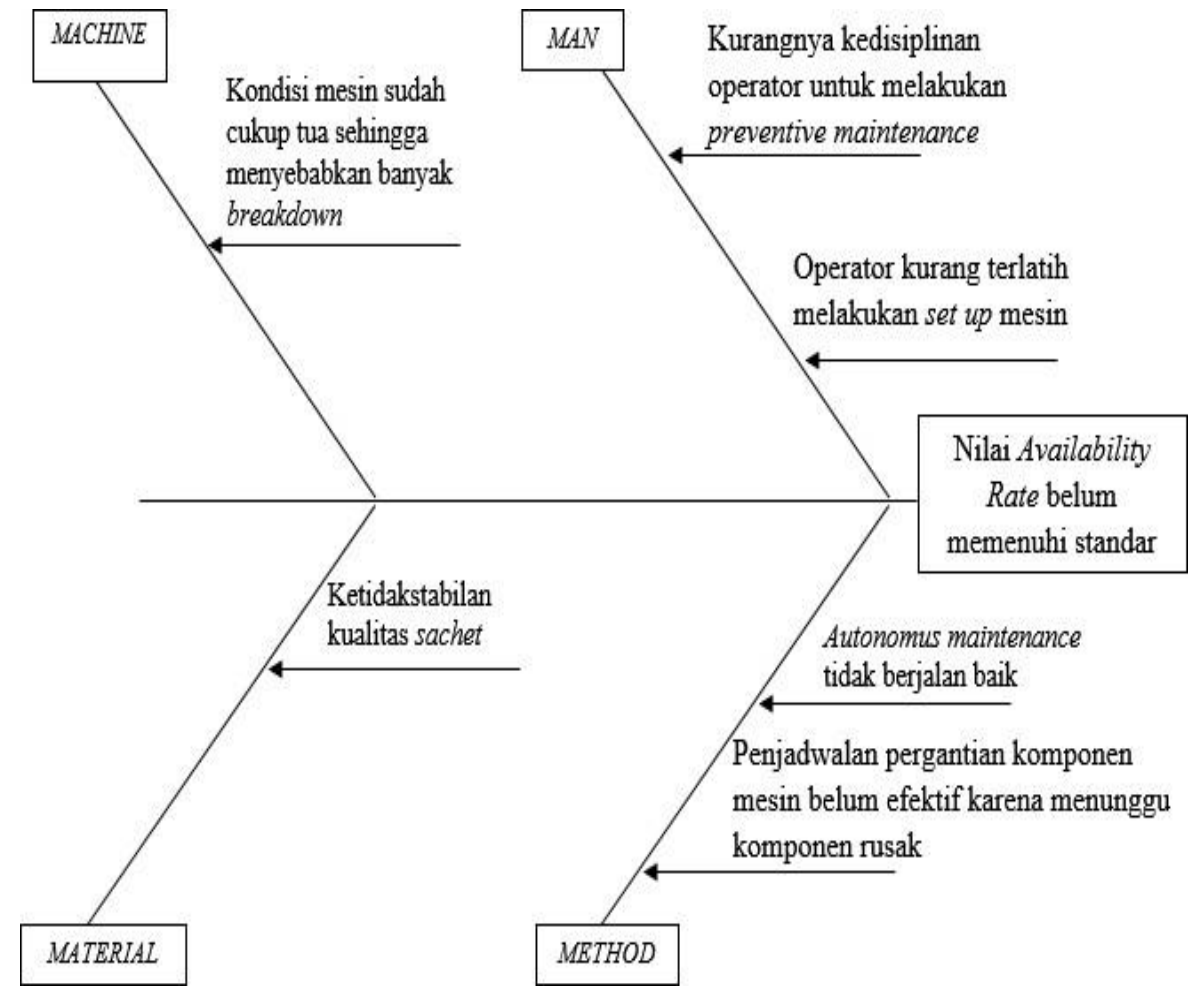

Gambar 4 Diagram Ishikawa nilai avaliability rate

Karena environment tidak termasuk penyebab rendahnya nilai environment, maka environment tidak digambarkan pada diagram ishikawa.

\section{G. Analisis Usulan Perbaikan}

Setelah melakukan analisis permasalahan dengan diagram Ishikawa, berikut adalah saran perbaikan yang dilakukan untuk perusahaan terhadap faktor minimnya availability rate pada mesin performance rate SKM:

TABEL III

USULAN PERBAIKAN BERDASARKAN DIAGRAM ISHIKAWA

\begin{tabular}{|c|c|c|}
\hline Faktor & Faktor Penyebab & Usulan Perbaikan \\
\hline \multirow{13}{*}{ Man } & Operator kurang & \multirow{10}{*}{$\begin{array}{lr}\text { Melakukan program } \\
\text { KPI per individu dan } \\
\text { melakukan reward and } \\
\text { punishment } & \text { serta } \\
\text { melakukan } & \text { evaluasi } \\
\text { setiap } & \text { minggu, } \\
\text { memberikan } & \text { insentif } \\
\text { yang sesuai } & \text { untuk } \\
\text { mendorong } & \text { kinerja } \\
\text { operator, } & \text { dan }\end{array}$} \\
\hline & disiplin & \\
\hline & melakukan & \\
\hline & preventive & \\
\hline & maintenance. & \\
\hline & Contoh: & \\
\hline & -Pisau sering tumpul & \\
\hline & tapi tidak & \\
\hline & menggantinya & \\
\hline & sebelum tumpul. & \\
\hline & -Pusher kendor & memberikan \\
\hline & -Tidak melumasi & pengawasan dan \\
\hline & $\begin{array}{l}\text { secara berkala saat } \\
\text { pergantian shift }\end{array}$ & $\begin{array}{l}\text { pengarahan kepada } \\
\text { operator }\end{array}$ \\
\hline
\end{tabular}

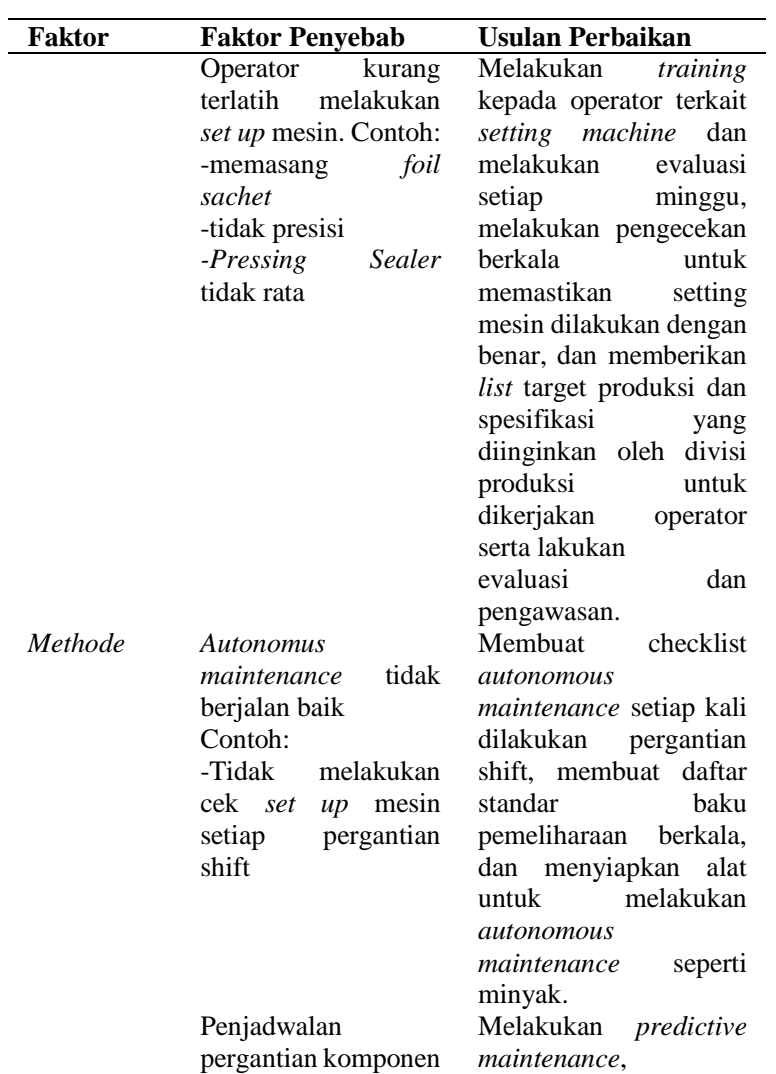




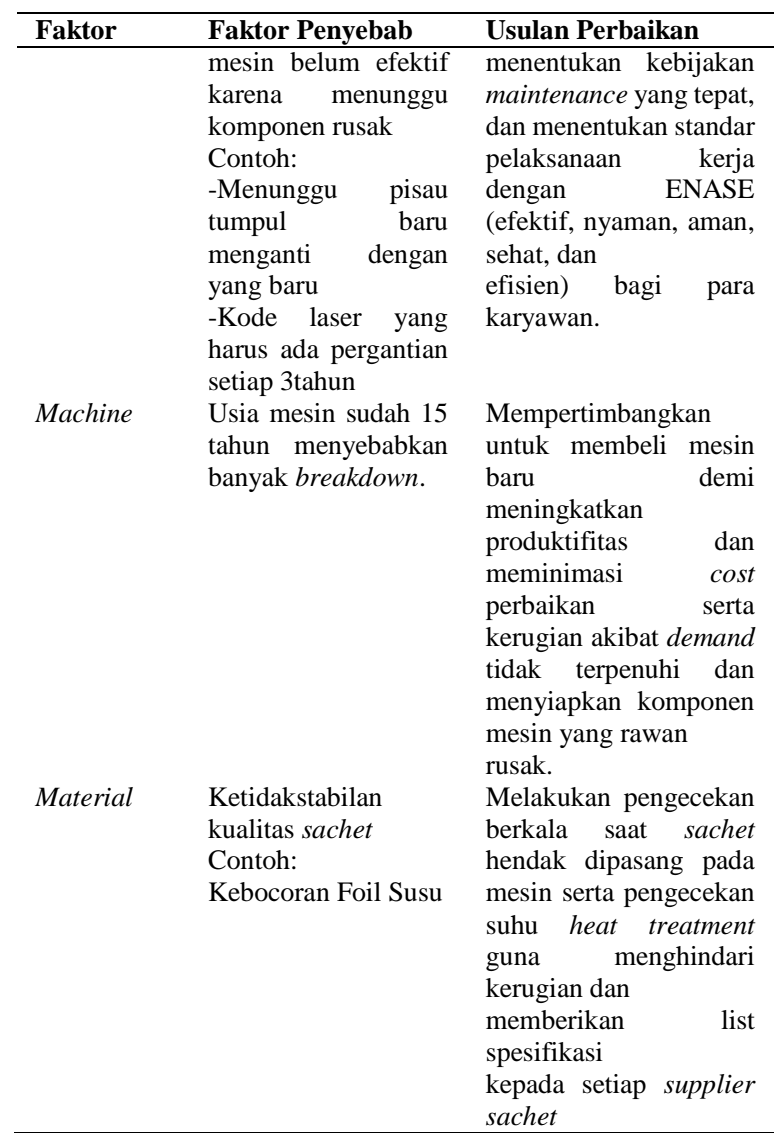

Dari hasil di atas dapat ditentukan ide - ide perbaikan apa saja yang dapat meningkatkan nilai availability rate mesin performance rate SKM pada PT. X Jika nilai availability rate meningkat hal tersebut dapat sangat membantu dalam peningkatan nilai OEE mesin performance rate SKM hingga mencapai target OEE dari PT. X.

\section{H. Analisis Return Of Investement}

Return of investment adalah pengukuran performansi yang dilakukan untuk mengevaluasi seberapa efisienkah investasi yang akan kita lakukan. Berdasarkan hasil saran atau usulan perbaikan di atas mengenai pergantian mesin performance rate SKM, penulis akan membuat return of investment mengenai pergantian mesin performance rate SKM.

$$
R O I=\frac{\text { Total Penjualan-Investasi }}{\text { Investasi }} \times 100 \%
$$

Penyelesaian:

$$
\begin{aligned}
& \text { Rata }- \text { rata Total Penjualan } / \text { Thn }=243109 \\
& \text { crt } \\
& \text { Harga } / \text { Karton }=\text { Rp. 120.000,- } \\
& \text { Investasi } \quad(\text { Pembelian Mesin })=\text { Rp. } \\
& \begin{array}{l}
180.000 .000,- \\
R O I=\frac{((243109 \times 120.000)-180.000 .000}{180.000 .000}
\end{array} \times 100 \% \\
& \quad=161,07 \%
\end{aligned}
$$

Setelah menghitung ROI dapat dilihat bahwa margin keuntungan dengan membeli atau mengganti mesin filling sachet SKM akan menghasilkan untung $161,07 \%$ sehingga dengan menginvestasikan uang untuk membeli mesin tidak akan merugikan perusahaan.

\section{KESIMPULAN}

Dari Analisa data selama bulan JanuariDesember 2020 yang dilakukan dapat diperoleh kesimpulan sebagai berikut:

1. Nilai rata - rata untuk availability rate adalah sebesar $77.71 \%$.

2. Nilai rata - rata untuk Performance Rate adalah sebesar $93.00 \%$.

3. Nilai rata - rata untuk quality rate adalah sebesar $99.99 \%$.

4. Nilai rata - rata untuk $O E E$ adalah sebesar $71.90 \%$.

Dari rata - rata nilai OEE pada bulan Januari Desember pada PT. X disimpulkan sudah cukup baik karena sudah diatas $60 \%$, pernyataan ini mengacu pada tabel klasifikasi standar dunia $O E E$ yang dibuat oleh Japan Institute of Plant Maintenance. Tetapi karena nilai $O E E$ ini belum memenuhi nilai $O E E$ yang ditargetkan perusahaan yaitu $75 \%$ dan belum memenuhi nilai $O E E$ standar dunia yaitu $85 \%$, artinya masih banyak ruang yang tersedia untuk improvement.

\section{REFERENSI}

[1] Jonsson, P., \& Lesshammar, M. Evaluation and improvement of manufacturing performance systems - the role of OEE. International Journal of Operations \& Production Management, 1999.

[2] Ljungberg, O. Measurement of Overall Equipment Effectiveness As a Basis for TPM Activities. International Journal of Operations \& Production Management, 1998.

[3] Nakajima, Siichi. "Introduction to Total Produktive Maintenance (TPM)”: Cambridge. Massachussets, 1988. 